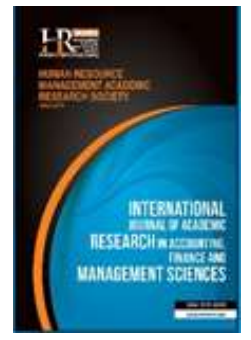

International Journal of Academic Research in Accounting, Finance and Management Sciences

Vol. 9, No.4, October 2019, pp. 24-29

E-ISSN: 2225-8329, P-ISSN: 2308-0337

(C) 2019 HRMARS

www.hrmars.com

To cite this article: Anghelache, C., Grigorescu, D.L., Radu, I. (2019). Models Used in the Analysis of Production and

Consumption, International Journal of Academic Research in Accounting, Finance and Management Sciences 9 (4):

24-29

http://dx.doi.org/10.6007/IJARAFMS/v9-i4/6629 (DOI: 10.6007/IJARAFMS/v9-i4/6629)

\title{
Models Used in the Analysis of Production and Consumption
}

\author{
Constantin Anghelache ${ }^{1}$, Dana Luiza Grigorescu², lulian Radu ${ }^{3}$ \\ ${ }^{1}$ Bucharest University of Economic Studies/„Artifex” University of Bucharest, Romania, ${ }^{1}$ E-mail: actincon@yahoo.com \\ 2,3 Bucharest University of Economic Studies, Romania, ${ }^{2}$ E-mail: danaluiza2004@yahoo.com, ${ }^{3} E$-mail: julian@linex.com
}

\begin{abstract}
The production of a country is done in order to provide the resources for the general final consumption of the population, but also consumption we consider the use of results of the previous or current period in the development of production and for investments. From the production function of Coob-Douglas we know that the economic activity is carried out using three factors namely capital, labor and material-financial resources. Production is the main factor, meaning, we will analyze the possibility of using and adapting macroeconomic models to such a complex analysis. We also addressed consumption issues because economic growth is based on mixed consumption or investment. As in the case of Romania this economic growth is mainly achieved through consumption, we have granted a series of privileges to treat such a model. We logically identified the nature of the correlations that arise at the level of macroeconomic production, presented the new variables that should be taken into account, we referred to the basic macroeconomic model and through the used examples we concluded how to use such a model.

Key words

Production, Consumption, Model, Function, Capital, Resources

Received: 25 Nov $2019 \quad$ C The Authors 2019

Revised: 02 Dec 2019 Published by Human Resource Management Academic Research Society (www.hrmars.com)

Accepted: 03 Dec 2019 This article is published under the Creative Commons Attribution (CC BY 4.0) license. Anyone may Published Online: 06 Dec 2019 reproduce, distribute, translate and create derivative works of this article (for both commercial and non-commercial purposes), subject to full attribution to the original publication and authors. The full terms of this license may be seen at: http://creativecommons.org/licences/by/4.0/legalcode
\end{abstract}

\section{Introduction}

In this article, the authors focused on identifying the conditions to be met in order to decide on a production and consumption model considering simple linear models or models that highlight the evolution of production, the role of consumption in society, the need for investment. One by one, the usable macroeconomic models were established and analyzed, a study was carried out on the relationships between the two elements, production and consumption, the variables that can be considered subjecting to a logical study the data series and graphical representations were identified. Give the significance of the tendency and even the intensity of the correlations that emerge between the variables. Then, the basic macroeconomic model was broadly addressed, which was then exemplified by the conditions of maintaining the balance of such a model or presented some data that argue the appreciations expressed by the authors.

\section{Literature review}

Anderson et al. (1992) are concerned with the estimation and interpretation of the yield curve. Anghelache et al. (2019) analyzes the main indicators of national wealth that have an effect on macroeconomic performance. Anghelache and Anghel (2019a) addresses in their work theoretical and practical aspects regarding economic statistics. Anghelache and Anghel (2019b), it addresses the problems 
of economic modeling. Barndorff-Neilsen et al. (2008) analyzes in their work the ex-post variation of equity prices in the presence of noise. Berman (1964) addresses the limits for the maximum term in stationary sequences. Black (1972) analyzes the balance of the capital market under the conditions of restricted loans. Hansen and Lunde (2006) addresses issues related to forecasts for volatile models. lacob (2019) analyzes the capital coefficient, the acceleration coefficient and the productivity of investments. Stambaugh and Yuan (2017) raise the issue of factors not taken into account that influence the various economic phenomena.

\section{Methodology, data, discussions, results}

Simple classification of models is not sufficient. We aim to analyze not only 'what' but 'why' and 'how' to build a macroeconomic model. It is not enough to have a good system of definitions, even a good system of data and measurements. We will also do something about the random factors involved in the economic systems. It is not enough to measure the national income and its distribution. We are also interested in why the national aggregates and their different components are and why they show their different changes and fluctuations. The construction of economic models is an attempt to give some answers to the question of the determinants of the economic system - an answer, that is to the questions "why and how".

What do we mean when we ask ourselves: why is the national income not? We can mean many things, depending on the level of argumentation. In the economic analysis, however, we consider that we have a satisfactory answer to the above question if we can specify that there is a system of relations between the different variables of the system that are satisfied, if these variables represent what they are. Such a relationship system is called a model; there are two main types of these models: equilibrium and dynamic. In equilibrium models, the system of relations can be expressed as a set of equations or identities that can be satisfied only by a set of values of the various variables that the equations include. In order to obtain these conditions, an equal number of equations and unknowns must be determined according to the number of variables. In dynamic models, the values of the present variables are clearly correlated with the values of these variables of the past, which, in turn, are related to the variables from the more distant past and so on in infinite regress.

\section{- Identities}

The model concept will become clear as we present some examples. The relationships that constitute a model are of two types, identities and behavioral equations. All models seem to have both. Identities are true by definition. These are generally obtained by taking a given aggregate and expressing it as a sum of elements or as a product of the components. If then we put an aggregate total with the sum of its parts or if we equate two different breakdowns of the same aggregate, we will have an identity. Thus, any human population (N) can be divided into coded people (S) and the rest coded (T) and we can write:

\section{$\mathrm{N}=\mathrm{S}+\mathrm{T}$}

The same population can also be divided into coded people $(\mathrm{J})$ and the rest coded $(\mathrm{K})$, according to the relationship:

$$
\mathrm{N}=\mathrm{J}+\mathrm{K}
$$

from which other identities derive, such as:

$$
\mathrm{S}+\mathrm{T}=\mathrm{J}+\mathrm{K} \text { sau } \mathrm{S}-\mathrm{J}=\mathrm{K}-\mathrm{T}
$$

It seems that we have derived a theorem that the excess of $\mathrm{S}$ over $\mathrm{J}$ in any population must be equal to the excess of non-J with respect to non-S. These particular identities are not very interesting, although no one can deny the truth. They are not interesting, because the aggregates they represent are not particularly interesting, at least for the economist. If it is true that the number of forces and Js were occasionally or empirically related, the above identities could become part of a model. Suppose that the Ss formed a tight driving class and had an inflexible rule, namely that the number of non-Ss should always be equal to the $S$ number, and in addition, always keep their own numbers at 1000 , we would have a model under the conditions under which the equilibrium value of all variables could be deduced. It would be 
expressed in three relations: identity $\mathrm{N}=\mathrm{S}+\mathrm{T}$ and two behavioral equations, $\mathrm{S}=\mathrm{T}$ and $\mathrm{S}=1000$. As there are three unknowns, $\mathrm{N}, \mathrm{S}$ and $\mathrm{T}$, these three equations can be solved, obtaining values of $\mathrm{N}, \mathrm{S}$ and $\mathrm{T}$ that satisfy all three relations simultaneously. In this case there is only one solution: $\mathrm{N}=2000, \mathrm{~S}=1000, \mathrm{~T}=$ 1000.

\section{- Behavioral equations}

Behavioral equations are relationships that express certain empirical aspects of the behavior of individuals in the system. They are not necessarily true, as identities must deduce their validity from empirical observation. If they are not satisfied, the behavior and, therefore, the change will occur and will not cease until they are satisfied. Consider the total population was 2500, with $1000 \mathrm{~S}$ and 1500 non-S. Following the behavioral rule, the Ss should eliminate 500 non-Ss to bring their number to equality, which would reduce the population to 2000 . If the population were 2500 , divided by $1250 \mathrm{~S}$ and 1250 non-S, both rules would come into play: 250 Ss would be eliminated to reduce the $S$ population to 1000 legal entities and 250 non-Ss would be eliminated to bring the numbers of the two groups equal. If the total population were 1500, $750 \mathrm{~S}$ and 750 non-S, the S population would be allowed to grow to 1000, and the non-S population would be allowed to grow equally, bringing the total population back in 2000 . It is obvious that the balance is stable. If $\mathrm{N}$ is not 2000 , steps must be taken to restore equality. What the population will be at any given time depends on the dynamic relationships involved in a fast or slow moving equilibrium. However, in equilibrium models, we only consider the equilibrium position.

- Increase the number of variables by adding new variables

Models can be built as simple or complicated as we wish, by adding or removing variables and new relationships. When we add an independent equation or identity (i.e. one that cannot be derived from existing relationships) for each new variable, the model is extended (complicated). If we give up a variable, the model becomes simpler. Suppose we add a new variable to the previous model, say, the number of J. To ensure that the model will be determined, we must identify a relationship between $\mathrm{J}$ and the other variables. Consider that the only function of J was to reduce $\mathrm{S}$ and that each J would have a parity of $20 \mathrm{~S}$. In this case, in the equilibrium function, we would have an additional relation: $20 \mathrm{~J}=\mathrm{S}$, as we know that in equilibrium $S=1000, J=50$. If we now want to determine the number of non-J, $K$, this new variable can be denoted by identity, equation (2), so that $K=1950$.

The above argument is reduced to the extreme, by the fact that behavioral equations are least likely to be found in a real society. An absurd case illustrates the generalization of a principle better than a realistic one and it is not difficult to resort to more realistic models that involve economic variables.

- The basic model of macroeconomics

The simplest, but most important, macroeconomic model is the one that establishes the correlation between the three relationships and three variables. Let $P$ be the total physical result of a company in a given period. Let $C$ be the value of this physical output consumed during the period, and $A$ be the accumulated (invested) quantity, that is, added to the stocks. In these conditions we have a relation of form:

$\mathrm{P}=\mathrm{C}+\mathrm{A}$

The concepts must be defined so that this equality is certain. What is found in reality is that what was produced in a certain period must be consumed in that period, or invested (stored). Production is conceived as an additional addition to the total stock, i.e. consumption as a decrease from the total stock, the accumulation being the difference between what was added and what was consumed. This is the existing level for investments.

Regarding accounting concepts regarding national income, we can define $\mathrm{P}$ as the net national product, $\mathrm{C}$ as the sum of personal consumption expenses (B1) and government purchases (J1) and $\mathrm{A}$ as the sum of net private domestic investments (C1) and net exports (I1).

- Consumer and investment functions

In addition to equality (4), two behavioral equations are required, respectively:

$$
\begin{aligned}
& C=F_{c}(P) \\
& I=F_{i}(P)
\end{aligned}
$$


We do not consider an exact algebraic relation, but a general function. Equation (5) is coded C, being a function of $P$. It means that this quantity of consumption depends on the volume of production realized, so that for each value volume of production corresponds a single quantity of consumption that is in accordance with it. A behavioral equation is not useful enough unless there is a safe behavior behind it. The link here is that the decisions to consume from individuals, insofar as they have the freedom to choose, are very closely linked to their individual incomes. In principle, the higher a person's income, the higher the consumption. Personal income is correlated with total output, P. For any given value of $\mathrm{P}$, it is likely that there is a given value of personal income, and for each value of personal income there will be a quantity of consumption. It is unrealistic to assume that, with a given distribution of incomes and stable forms of individual consumer behavior, there is a sufficiently defined relationship between total production and consumption volume achieved.

The behavioral models underlying the accumulation equation, (6), are more complex. What the equation expresses is that, for any output level, there is only one value of total accumulation that is consistent with the given output level. This means that at each level of output there is a certain level of accumulation, which is avoidable for people who have increased stocks of goods, coded I.

We deduce that an additional equation is needed to ensure the equilibrium conditions, respectively:

$A=1$

In other words, we consider that the actual accumulation level must be equal to the level that ensures the balance.

If the actual accumulation level is higher than the equilibrium level, the people who have sufficient goods will use them on the market. Manufacturers, wholesalers, retailers and households holding too large stocks of goods will capitalize on them through the market. We will assume that the easiest way to reduce stocks if the market is saturated is to reduce production. But consumption is given (for each $\mathrm{P}$ value), so there are not many opportunities to reduce stocks, just by expanding consumption. Similarly, if the actual accumulation level is lower than the value at a satisfactory level, producers will try to increase stocks. Manufacturers can only increase stocks through additional production. If the producers consider abundance of a product they reduce the purchases of the product, and the reduced purchases lead to an overvaluation by the seller, which reduces the purchases from the wholesaler; reduced purchases from retailers lead to over-storage at wholesaler, which reduces purchases from the manufacturer. The manufacturer responds to the resulting over-stock, reducing production. Through a similar chain, subcontracting anywhere in the system will increase production, as long as there are unused financial resources.

Therefore, we notice that if the behavioral equations are not satisfied, certain behavioral changes will occur and if the equilibrium is stable, these changes will work to adjust the values of all system variables in a direction that ensures equilibrium. This process will continue until the equations are satisfied, at which time there will be no behavioral changes and the system will reproduce in equilibrium until new situations appear that tend to unbalance the considered system.

- Statistical-mathematical example of macroeconomic balance

This simple model can be illustrated by statistical-mathematical and graphical examples. Table 1 shows the relationship between total output $(P)$, those consumption levels $(C)$ and accumulation $(A)$, which are corresponding to each level of production.

Table 1. Macroeconomic equilibrium

\begin{tabular}{|l|l|l|l|l|l|l|l|l|l|l|l|}
\hline production (P) & 0 & 20 & 40 & 60 & 80 & 100 & 120 & 140 & 160 & 180 & 200 \\
\hline consumption (C) & 60 & 73 & 87 & 97 & 106 & 113 & 120 & 126 & 130 & 134 & 137 \\
\hline investment (I) & -30 & -13 & 0 & 7 & 15 & 21 & 24 & 27 & 30 & 32 & 34 \\
\hline total absorption (I+C) & 30 & 60 & 87 & 104 & 121 & 134 & 144 & 153 & 160 & 166 & 171 \\
\hline effective accumulation (P-C) & -60 & -53 & -47 & -37 & -26 & -13 & 0 & 14 & 30 & 46 & 63 \\
\hline $\begin{array}{l}\text { accumulation of surplus [P-(I-C)] } \\
\text { deficit accumulation [(P-C)-I] }\end{array}$ & -30 & -40 & -47 & -44 & -41 & -34 & 24 & -13 & 0 & 14 & 29 \\
\hline
\end{tabular}


The relationship between production and consumption, $C=F_{c}(P)$, is considered to be the function of consumption. The relationship between production and accumulation $I=F_{i}(P)$, is the investment function, the investment being defined as the amount of accumulation that is in accordance with a given level of production.

Interpreting the data in table 1 , we reach the following conclusions: if the output were 0 , the company would be willing and able to consume 60 and would be willing and able to invest - 30 (ie to divest or accumulate 30 ); if production were 20 , the company would be willing and able to consume 73 and invest - 13 and so on. The fourth line of the table shows the algebraic sum of consumption and investment. What is shown in row four is total absorption. If we consider consumption and investment (accumulation) as the only two ways in which the product can be absorbed or used, the total consumption and investment together show the total amount of product that will be absorbed by the system. If the actual production is greater than the total absorption, there will be additional accumulations; if the actual production is less than the total absorption, there will be deficits and, as we have seen, they will produce behavioral changes that will influence the change of the production.

- Some assumptions of the consumption (investment) model (function)

The data in table 1 are based on certain assumptions regarding the nature of consumption and investment functions. These assumptions are plausible. The actual form of the function is a matter of fact, in each case, which can only be determined by empirical research. Thus, we assumed that at a zero production level, if such a factual state existed, there would still be some consumption (60), since the existing capital is depreciated, and people must eat even if they do not produce. In such a situation, someone is unlikely to be willing to invest (accumulate). At very low levels of production, the company is only willing to consume from existing stocks. When we have higher levels of production, both consumption and investment increase. Suppose that both grow at a growth rate, so that a unitary increase in production leads to a small increase in $\mathrm{C}$ and $\mathrm{A}$ compared to the unitary growth of production at low levels.

- Accumulation surplus or deficiency (investments)

If we subtract the total absorption figure from the output figure, we obtain a measure of surplus or deficiency in the actual accumulation (row 6 , table 1). If there is a surplus of accumulation, this means that at these levels of production, the actual accumulation is greater than the expected accumulation. If there is an accumulation deficit, because there is a value less than 160 , then the actual accumulation is less than the level considered.

We conclude that the real accumulation (row 5) is the difference between production and consumption. The accumulation surplus or deficit can be obtained by subtracting the accumulation, row 3 from the figures corresponding to row 5 .

\section{Conclusions}

From the article aspects regarding production and consumption models, based on an extensive study, can be drawn a series of theoretical and practical conclusions. First of all, from a theoretical point of view, it is necessary to express the opinion that the realization of a macroeconomic model regarding production and consumption must be based on a few steps. First of all, the series of data for an extended period of time must be studied to identify the trends that are established between the two or more variables. Production intended for consumption and investment. Consumption, especially for countries like Romania, plays an important role in economic growth although it is limited in time. In this sense we also made graphical representations to highlight the economic trends.

The second conclusion is that the statistical-econometric models thus established must be formalized in equations, system of equations, by whose resolution we identify the parameters for estimating the activity at the macroeconomic level, regarding, of course, in our case, the evolution of production and of consumption.

Also, it must be kept in mind that within this evolution there is at one point a moment of equilibrium in which the market demands are satisfied by the production, and it is the consumption that directs the market in the sense that what is required must be multiplied in production, what is stored must be disposed of. 
Another conclusion would be that only on the basis of such a study can a convincing relevant macroeconomic evolution be ensured.

\section{References}

1. Anderson, N., Breedon, F., Deacon, M., Derry, A., \& Murphy, G. (1992) Estimating and Interpreting the Yeld Curve, John Wiley Series in Financial Economics and Quantitative Analysis.

2. Anghelache, C., Anghel, M. G., Marinescu, A. I. (2019), The main indicators of national wealth that have an effect on macroeconomic performance, Romanian Statistical Review, Supplement, no. 3, pp. 14-2.

3. Anghelache, C., Anghel M. G. (2019a), Statistică economică generală, ediția a doua, revizuită și adăugită, Editura Economică, Bucureşti, 524 pp.

4. Anghelache, C., Anghel, M. G. (2019b), Modelare economică. Teorie şi studii de caz, ediția a doua, revizuită și adăugită, Editura Economică, Bucureşti, 404 pp.

5. Barndorff-Neilsen, O., Hansen, P., Lunde, A., \& Shephard, N. (2008), Designing Realised Kernels to Measure the Ex-Post Variation of Equity Prices in the Presence of Noise, Econometrica 76, 1481-536.

6. Berman, S. M. (1964), Limit Theorems for the Maximum Term in Stationary Sequences, Annals of Mathematical Statistics 35, 502-16

7. Black, F. (1972), Capital Market Equilibrium with Restricted Borrowing, The Journal of Business, 45.3, 444-55.

8. Hansen, P.R. \& Lunde. A. (2006), A Forecast Comparison of Volatility Models: Does Anything Beat a GERCH $(1,1)$ ?, Journal of Applied Econometrics 20, 873-89.

9. lacob, S. V. (2019), Utilizarea metodelor statistico-econometrice și econofizice în analize economice, Ed. Economică, 216 pp.

10. Stambaugh, R.F. \& Yuan, Y. (2017) Mispricing Factors, Review of Financial Studies 30, 1270-315. 